The Sri Lanka Journal of the Humanities (2018) 42: 1-2, 54-85

DOI: http://doi.org/10.4038/sljh.v42i1-2.7255

Published online: 28 November 2019

(C) University of Peradeniya

\title{
Location of Cultural Value: Historicizing Virägaya as a Novel on Postcolonial Subjectivity
}

\author{
LIYANAGE AMARAKEERTHI ${ }^{1}$ \\ ${ }^{1}$ Department of Sinhala, University of Peradeniya \\ ${ }^{1}$ liyanage19@gmail.com \\ 1 (iD) https://orcid.org/0000-0002-5744-4484
}

\begin{abstract}
Martin Wickramasinghe's Virāgaya (1956), a novel considered a modern classic is often understood be a text that exclusively focuses on the inner psyche of the central character. Thus, it was criticized for the lack of socio-political meaning. Amarasekara, a renowned writer and critic, maintained that the novel represents a certain weakening of socio-political dialogue in the country after achieving independence from the British. Compared to Wickramasinghe's famous trilogy, which is explicitly 'social' since it deals with an evolution of a certain capitalist class, Virāgaya is understood to be a work that deals more with the psychological than with the social. This paper argues that when read as a postcolonial novel, contextualizing it in its specific postcolonial condition, Viragya appears to be much more 'social' and 'political' than any other novel
\end{abstract}


that appears to be so. Aravinda (the literal meaning of the name being 'the lotus'), the central character of the novel, is a man who embodies detachment, which is an important Buddhist value. His detachment is shown by the way he maintains a certain aloofness vis-à-vis the accepted social norms, which is often interpreted as a legacy of his Buddhist upbringing. This paper argues, in contrast, that it is the colonial/postcolonial condition that allows him to maintain a detached life. For example, the stable income he receives as a clerk in the Ceylon Clerical Service creates the material condition for him to lead his detached life even though the idea of detachment has its origin in Buddhism. Thus, this close reading of the text aims to provide some insights into the way we understand colonial/postcolonial subjectivity.

Keywords: Novel, Colonial, Postcolonial, Subjectivity

"It is rather disturbing to realize that the evolution of the modern Sinhala novel began with Gamperaliya, and ended with

Viragaya." Tissa Abeysekara (Roots, Reflections and

Reminiscences 119)

Martin Wickramasinghe's Virāgaya (1956) is almost universally treated as his masterpiece, and, for some critics, as the above epigraph attests, it is the greatest novelistic achievement in the history of the Sinhala novel. The novel, however, has generated another important debate about how a novel could deal with socio-political realities of a society. This much-loved novel is taken to be an ahistorical and apolitical text that set up a trend for a host of other 'apolitical' novels. In addition, it is claimed that the novel that does not portray the social aspects of the times in which it was written began a trend of novels with introvert characters.

The main proponent of the above arguments about Virāgaya is Gunadasa Amarasekara who is a well-known writer and an influential public intellectual often taken to be the father of the Jâtika Cintana Movement--a Sinhala nationalist political-cultural movement whose 
origin goes back to the $1980 \mathrm{ss}^{1}$ In this paper I want to problematize this argument and make the case that Virāgaya can be read as a postcolonial novel and, as such, it is quite 'political.' I want to argue that when situated in postcolonial discourse/s, Virāgaya begins to generate an array of interesting themes related to the notion of the ideal Sinhala citizen of postcolonial Sri Lanka. Aravinda, the central character of the book seems to represent Martin Wickramasinghe's hope, doubts and fears about the Sinhala Buddhist postcolonial citizen. In that sense, Virāgaya, a novel with minimal drama, is much more social-political than the author's explicitly social novels such as Gamperaliya, Kaliyugaya and Yugāntaya, a trilogy whose first book, according to Sarachchandra, is the "first realist Sinhala novel" to achieve the artistic finesses of the genre (The Sinhalese Novel).

In this paper, I argue that Virāgaya's socio-political meanings could be elucidated when it is historicized as a postcolonial text. 'Postcolonial' is very much a contested term, and there is vibrant and often esoteric debates about and around the term. Without being sidetracked into those debates, I want to produce a reading of this Sinhala novel. In relation to Virägaya, I use the term postcolonial to indicate the layers of meaning associated with the central character of the text that cannot be fully realized without referring to the colonial condition, which the character inhabits. Though it is difficult to discern the exact time period during which the story of the novel is set, the text is postcolonial at least in two ways: It was published in 1956, eight years after Sri Lanka gained independence at a time when the Sri Lankan intellectual scene was reflecting on its colonial legacy, and the novel seems to be concerned with some of the existential issues of an educated man from rural middle class. And those issues stem from the postcolonial condition that he inhabits. A certain dualism in the consciousness of the central character, as I will explain later, looks to be resulting from the postcolonial condition that has split his consciousness forcing him to oscillate between oriental wisdom and the forms of knowledge provided by colonial modernity.

\footnotetext{
${ }^{1}$ Harshana Rambukwella's excellent new book includes an insightful analysis of Amarasekara's career as a nationalist thinker. See Rambukawella 102-136.
} 
When attempting to bring what I call postcolonial condition to bare upon the text, it becomes apparent that the specific consciousness of the central character could only be found in a postcolonial situation to use the term 'postcolonial' to mean the early twentieth century, both before and after independence in 1948. This paper does not intend to participate in often obscure theoretical discourses in the field of postcolonial theory; nevertheless, it aims to produce a somewhat complex reading of a modern Sinhala classic, and, in that sense, this is a paper in literary criticism—a decidedly humble aim.

\section{Basic Plotline}

Aravinda is the only son of a rural Aurvedic physician, who is open to newness in society and wants his son to be a Western doctor. Aravinda, however, does not want to be a doctor and confesses to his mother that he does not like operating on female bodies. Apart from that, on his own admission he does not have a desire to be a doctor or a scholar. This 'desirelessness' (or the lack of attachment or virägaya) seen in him even during his school days is developed into virāgaya "desirelessness" which is the novel's key thematic concept. After the senior school exam in the English medium, Aravinda falls in love with Sarojini, a beautiful girl from a wealthy family in the village, but he does not make an attempt to marry her even when he can. His plans for further education collapse with his father's untimely death, and he ends up becoming a government clerk with a considerably stable income. But, even then, he does not agree with Sarojini's suggestion to get married without her parent's consent. He later interprets his inaction as an expression of 'desireless desire'. When Sarojini informs him that she is ready to elope, Aravinda does not agree with her-a decision that costs him his girlfriend who then marries a successful businessman who happens to be Aravinda's cousin. Aravinda lives the rest of his life alone reading extensively and conducting alchemical experiments while working as a clerk in a government office. Towards his mid years, he hires a domestic servant who happens to be a helpless mother of a little daughter. The mother and daughter live in Aravinda's home practically like a family, though it is clear that Aravinda and the mother, or Aravinda and the daughter, do not have any sort of physical intimacy. 
The little girl grows up as his adopted daughter to whom, as he later admits, Aravinda's attraction was almost sexual. His life with these two women, though is a source of gossip, seems the ideal life he could have had. Aravinda dies rather young of a mysterious disease that has to do with blood poisoning, leaving behind a manuscript of his autobiography, which makes the novel. Other than the close examination of Aravinda's life, in its inner make-up, the novel does not have any dramatic events, a point I will return to later in this paper. It is a plot-less, slow-moving, and meditative memoir written by Aravinda himself.

\section{Virägaya and the 'Lack' of Social Significance}

In 1976, Gunadasa Amarasekara (b. 1929) wrote a slim book called Abudassa Yugayak ["An Age without a Buddha"] in which he presented a set of ideas that made a great impact on the Sinhala writers during the next thirty some years. This forty eight-page booklet is arguably the most influential piece of criticism on the Sinhala novel after Ediriweera Sarachchandra's Modern Sinhalase Fiction in 1946 and its Sinhala version Simhala Navakatha in $1951 .^{2}$ This booklet could be considered one of the key antecedents of Amarasekara's Jathika Chintana project. ${ }^{3}$ I shall move into this portion of the discussion by summarizing a comment that Amarasekara makes on the relationship between the novel and society.

\footnotetext{
${ }^{2}$ This text is the first ever treatise by a Sri Lankan scholar on the art of modern fiction. And it was pivotal in establishing a theoretical discourse on the artistic qualities of the modern Sinhala novel. The book, however, does not deal with the novel as an instrument in political struggles except that it mentions Piyadasa Sirisena's novels as part of the Sinhala nationalist struggle to gain independence from the British.

${ }^{3}$ Jātika Cintanaya or 'National Thought' is an influential intellectual trend that came into being in the early 1980s, and it maintained that in order for Sri Lanka to survive and flourish as a postcolonial nation it has to rediscover its native thoughts as a way of liberating itself from Western thought. While it is claimed that Amarasekara coined the phrase 'Jätika Cintanaya' (National Thought), Nalin de Silva, a professor in mathematics, developed the concept into a quasi-philosophy and a political ideology. Rambukwella succinctly summarizes Amarasekara and de Silva's intellectual collaboration in developing what they both called 'Jātika Cintanaya' (104).
} 
Borrowing the concepts of "base structure" and "superstructure" of classical Marxist thought, Amarasekara claims that the realist novel should reflect an on-going social discourse of a given society. In making this argument, Amarasekara seems to reinterpret Marxist theory. In classical Marxism, the superstructure, which is consists of art, culture, law, thought and the like, is determined by the base structure made of economic and social relations, the technologies of production and the relations of production. Thus, not only is literature a reflection of economic relations, it is also determined by them. This 'economic determinism' is a complex argument that has been simplified and distorted by many practical users of it. And Later Marxist thinkers have attempted to provide a much more nuanced explanation of the relationship between the base and the super structures. ${ }^{4}$

Amarasekara's appropriation of this theory may be seen as a distortion of the original Marxist thought, but in some ways, he is quite creative in his use of it. ${ }^{5}$ For example, he agrees that the social class that controls the economic base could only partially control what he calls 'the social dialogue', and the 'social dialogue' could sometimes move beyond the control of economic determinants. Rather than describing literature as a part of the social-political dialogue built on the economy, Amarasekara sees literature as an 'upper structure' (matu mahalaliterally, 'upper floor') built on the 'socio-political dialogue.' For him, literature is a 'trans-discourse' (uttara samvvādaya) built on the 'sociopolitical' discourse of a given society.

This concept of "a trans-discourse" (uttara samvvādaya) looks different from the notion of the super structure in that the former is a third layer of discourse based on the super structure: "literature is a

\footnotetext{
${ }^{4}$ Raymond Williams has attempted to complicate this dual structure in which one is determined by the other by employing the notion of 'totality' (158-178). We do not need to go into the details of that theoretical argument.

${ }^{5}$ Wijegunasinghe convincingly argues that Amarasekara's use of the concept of determinism is wrong and that he mistranslates and misuses Marxist theory (171188). Since it is not directly relevant to my argument in the paper, I will avoid going into that debate as well. Wijegunasinghe, however, does not pay attention to the innovative ways in which Amarasekara utilizes the basic premise of Marxist theory in question.
} 
trans-discourse based on social dialogue" which is in the super structure (Amarasekara, Abuddassa Yugayak 7). For Amarasekara, the literary and artistic practice of a society is a cumulative third layer rising above both the base structure and the super structure. He goes on to argue, "It can be said that it is the social discourse that guides the literary artist to find his or her subject matter" (8). As an example, he points out that Piyadasa Sirisena's nationalist novels reflected the social dialogue initiated by Anagarika Dharmapala, a key ideologue of Sinhala nationalism in the early Twentieth Century. ${ }^{6}$ Though debatable, Amarasekara's is an interesting point. One could argue against Amarasekara that writers are not mere mouthpieces of dominant ideologies, and that truly great writers in fact create counter-ideologies; however, that is a debate that is not directly relevant to the present discussion.

According to Amarasekara, Martin Wickramasinghe's trilogyGamperaliya (1944), Kaliyugaya (1956), and Yugāntaya (1949)represents a society vibrant with a rich socio-political dialogue. Since that trilogy, Amarasekara claims, the Sinhala novel has not had the support of such a socio-political dialogue. Dynamic socio-political dialogues are the forces that nourish the art of the realistic novel. $\mathrm{He}$ argues further that an important and vibrant socio-political dialogue came to an end, or culminated, in 1956 with S.W.R.D. Bandaranaike's ascent to power. After that particular landmark, the socio-political dialogue died down making Sri Lankan society silent or stagnant. According to Amarasekara, before the society became 'silent' that way, two sets of ideological discourses kept the society intellectually alive: the nationalist discourse led by Anagarika Dharmapala and the Marxist dialogue led by the leftist political parties. Wickramasinghe's trilogy represents the essence of those discourses (Amarasekara, Abuddassa Yugayak 16-25). This is a very short summary of an argument that

\footnotetext{
${ }^{6}$ Rambukwella has an excellent and lucid summary about Dharmapala's political/intellectual life. He claims, "In Sinhala nationalist discourse the ideological Dharmapala is a heroic anti-colonial figure and a man who signifies an organic link to an authentic Sinhala past. In much liberal scholarship the ideological Dharmapala is equally originary figure representative of racist and exclusivist Sinhala majoritarianism" (48-49).
} 
resists succinct paraphrasing. Though insightful in some places, Amarasekara's entire argument rests on his contention that the realist novel is a reflection/extension of a social dialogue taking place at a given moment. Wickramasinghe's trilogy comprises 'social' novels depicting a certain development in Sri Lankan society during the $20^{\text {th }}$ Century. Those novels capture some aspects of the development of a capitalist middle class and its conflicts with the Marxist movement. So they are decidedly 'outward' novels with the novelist's eyes set on the horizontal/historical flow of the society. Virāgaya, in contrast, moves vertically investigating the inner workings of a character's mind.

Amarasekara argues further that the post-Bandaranaike (post1956) 'silent society' could not continue to sustain the art of the realist novel and that that caused a gradual decline of that genre. For Amarasekara, Virāgaya, which is an 'introvert' novel that looks into the inner makeup of the central character instead of engaging with what I call the 'horizontal flow' of the society in which the character lives, marks the beginning of a series of novels that do not have a social dialogue to draw on or to 'lean on.' In making that argument, Amarasekara does not say that Virāgaya is a weak novel, though the other novels that follow the trend set by Virāgaya are not treated all that kindly by him. ${ }^{7}$ In fact, he denounced his own early novels that more or less followed the trend of the 'psychological novels,' a trend partly set by Virāgaya, that investigated the inner make-up of the central character/s (Amarasekara, Abuddassa Yugayak 32-3).

\footnotetext{
${ }^{7}$ Amarasekara is right in claiming that there were many novels which either imitated Virāgaya or were visibly influenced by it. It is unfair, however, to argue that those novels only followed the lead provided by Virägaya. By the 1950s, the ideas of literary modernism had entered the literary scene through the University of Ceylon at Peradeniya, and it was modernism (Joyce, Woolf, Proust and others) that emphasized that the novel could be used to investigate the inner consciousness of people. Dharmadasa's introduction to the English translation of Hevanælla explains the influence of modernism on the Sinhala novel during the 1960s. (See Dharmadasa.) Siri Gunasinghe, a scholar from Peradeniya, introduced techniques such as 'the stream of consciousness' to the Sinhala novel through his masterpiece Hevanælla in 1960. Amarasekara himself wrote at least two novels, which he later disavowed as a decadent form that investigate the inner lives of the characters.
} 
For Amarasekara, Martin Wickramasinghe's trilogy shows that the novelist was engaging with the 'social dialogue' of a certain historical period, while Virägaya shows the stagnant or 'dialogue-less' nature of the time in which it was written. He argues that when Wickramasinghe wrote his trilogy he was participating in the two parallel socialdiscourses at the time, namely the nationalist discourse of Angarika Dharmapala and the Marxist discourse. In the Twentieth Century, the first three decades of the Sinhala novel were nurtured by the nationalist discourse, while the two following decades were influenced by the Marxist discourse initiated by a group of young people who had come back to the country completing their education in England. Amarasekara goes on to explain how Marxist ideas shaped Wickramasinghe's views on social evolution. Yuganthaya, the last book of the trilogy, imagines a socialist Sri Lanka (Amarasekara, Abuddassa Yugayak 15-19). By 1956, however, Dharmapala's nationalist discourse had reached its intended peak with Bandaranaike's ascent to power (Amarasekara, Abuddassa Yugayak 23). After that victory, both social discourses that had animated Sri Lankan society and shaped the novelists' perspectives and vision died down creating a period of intellectual stagnation or a period of salience and slowness. Amarasekara has a detailed and interesting explanation of that shift, which I would not engage with at this point.

According to Amarasekara, the introvert nature of Aravinda who is the main character of the novel, which makes him avoid social engagements, represents the 'silent' and 'slow' nature of Sri Lankan society at the time. Compared to the central characters of the other novels by Wickramasinghe, Aravinda is a Bodhisattva who maintains an intentional distance with the others in his community. Piyal, the hero of Gamperaliya, for example, is a typical hero who accepts the received norms associated with the idea of 'success' and makes an effort to achieve that success in worldly pursuits. He makes money and marries a woman from a family that is 'higher' than his. Importantly, he marries the woman he loves. Aravinda, in contrast, does not make any effort to win any of those. Even his romantic relationship with Sarojini was more or less initiated by the girl herself. If the common characteristic of 
novelistic hero is to strive for success in worldly matters Aravinda is an anti-hero. His is a struggle with himself that takes place in isolation. ${ }^{8}$ Amarasekara's explanation of this aspect of Virägaya is interesting and important: By 1956, the year the novel was published, the kind of evolution of Sri Lankan society depicted in Wickramasinghe's famous trilogy, had come to an end. "This happens," Amarasekara argues, "when a novelist is unable to capture in his mind any forces that are growing and moving in a society or at a time when the movement of social forces is too slow and too weak for the novelist to capture (Amarasekara, Abuddassa Yugayak 28). Amarasekara concludes that Virāgaya is a product of this motionless society.

Amarasekara also argues that when the "social forces that had attracted the attention of a novelist" ceases toevolve the novelist tends to look into the 'inner aspects' of the people living in that society rather than turning to its outer aspects. ${ }^{9}$ When large socio-political forces are in motion a novelist can portray the characters in a manner that reflects the outer-social forces that are in operation and foregrounds the relations that those characters maintain with those forces, but when those forces are no longer in motion the novelists have to look into the inner lives of the characters, taking us inside the characters (Amarasekara, Abuddassa Yugayak 29). Amarasekara's point seems to be correct about many novels. At a time of major political or social upheavals, characters participate in or react to those events, and a writer can depict the characters by describing the way they react to those events. In such times, the non-reaction or non-participation of some characters in those social movements says a lot about who they are.

\footnotetext{
${ }^{8}$ Ian Watt in his classic study of the realist novel (1957) claims that a typical realist novel is about modern, secular man, usually all alone, struggling with the social forces of his society. Gamaperaliya whose hero is similar to the typical novelistic heroes described by Watt is very much a modern realist novel.

${ }^{9}$ Amarasekara claims that 'novella' or 'longer short story' is a better genre to write about that situation, and he goes onto argue that Virāgaya is a "long short story" (29), a point I refute strongly. For one thing, Virāgaya is a novel and the art of the novel can exist in many shapes. In addition, the writer's use of a genre-novel, novella or short story-is not decided by the social situation alone.
} 
Amarasekara does not criticize Virāgaya for avoiding what he calls the 'social-dialogue.' But he implies that Virāgaya opened up, though unwittingly, space for a series of other apolitical novels that aped Virāgaya. He may be right about many novels that imitated Virāgaya, but some of them, such as Siri Gunasinghe's Hevanæælla [“The Shadow"], are neither shadows of Virāgaya nor apolitical works. The argument that Virāgaya signifies a lack of social dialogue is the most problematic. Amarasekara's accusation is based on the fact that he considers only 'political and social grand narratives,' such as social evolution or class struggles, as 'political.' He ignores the political at the micro and personal level. That is in part because he had been influenced by early Marxist theories of socio-political analysis. ${ }^{10}$ In historicizing Virāgaya with a view to getting at its 'political,' one needs to be informed by later Marxist traditions, which offer a nuanced understanding of modernist literature. The following statement by Raymond Williams provides good guidance in this regard:

Moreover we should not, as socialists, make the extraordinary error of believing that the most people only become interesting when they begin to engage with political and industrial actions of a previously recognized kind. That error deserved Sartre's jibe that for many Marxists people are born only when they first enter capitalist employment. For if we are serious about even political life we have to enter that world in which people live as they can as themselves, and then necessarily live within a whole complex of work and love and illness and natural beauty. If we are serious socialists, we shall then often find within and cutting across this real substance- always, in its details, so surprising and often vivid- the profound social and historical conditions and movements which enable us to speak, with some fullness of voice, of a human history. (Williams 116)

When read in the relevant historical context, Aravinda's love, fear, compassion and loneliness all appear 'social' and 'political.' Here, the social and the political manifest themselves differently. Therefore,

\footnotetext{
${ }^{10}$ In theorizing the novel, he is very much a follower of Georige Lukacs who resented modernist fiction. Amarasekara, even in his latest writing on the art of the novel, remains a Luckasian in his approach (Amarasekara, Nosevnā Kædapata).
} 
the socio-political dimension of Virägaya is the kind, which Amarasekara and others expected from the novels of the mid-Twentieth Century. They wanted the socio-political thematic to be overt and pronounced. ${ }^{11}$ In Virägaya, however, as in many modernist novels, the layer of socio-political meanings is in the subtext, and they are articulated in a manner which is akin to the modernist techniques of fiction writing that foreground the 'stream of consciousness,' while keeping the socio-political context unpronounced in the background. Even though the modernist elements of Virāgaya have been implicitly acknowledged by many critics and the book has been regarded a classic by nearly all critics (Sarachchandra; Happuracchi), no one has recognized its potential to be read as a postcolonial text that portrays the subjectivity of the postcolonial Sri Lankan citizen.

1956 was a victorious year for Sinhala Buddhist nationalism. Martin Wickramasinghe himself was a celebrated supporter of S.W.R.D. Bandaranaike who came to power in that year. ${ }^{12}$ But Wickramasinghe the novelist may have wanted to imagine and examine the inner makeup of the Sinhala Buddhist person-an examination that is quite political at a time when Sinhala Buddhist nationalism has gained the most significant political victory in postcolonial Sri Lanka. ${ }^{13}$ For many

\footnotetext{
${ }^{11}$ A.V. Suravira, a key figure in the People's Literary Movement in the 1970s, expressed his reluctance to accept Virāgaya as a great work of art because of its modernist tendency to investigate into the inner life of the central character. Not surprisingly, Suravira utilizes Georg Lukacs's famous attack on literary modernism to claim that novels such as Virāgaya are weak since they move away from realism (139-143). It must be stressed, however, that Amarasekara was not a supporter of the People Literary Movement as well. He criticizes Suravira's propagandist novel Heyyammaruwa, a text that reminds one of certain Soviet novels (Abuddassa Yugayak 45).

${ }^{12}$ Wickramasinghe himself celebrated the 1956 electoral victory of Bandaranaike in his famous essay called "Bamunu Kulaya Bindawetima," (the downfall of the elite class) in which he argues that with the rise of Bandaranaike, the English educated colonial bourgeoisie were defeated. For him, the leaders of the United National Party were brown sahibs imitating the former colonizers. This essay was published in July 1956, and it has been influential in the Sinhala nationalist discourse ever since (Wickramasinghe, Samāja Dēśapālana Cintana).

${ }^{13}$ Now, the majority of the Sinhala Buddhists would claim that the Sri Lankan state's military victory over the LTTE is far more important than Bandaranaike's
} 
Sinhala Buddhists, the 1956 election victory was more important than gaining independence from the Crown eight years earlier. In this paper, I will demosntrate that Virāgaya is a fundamentally 'political' novel if we read it as a postcolonial text.

\section{Postcolonial Moments in the Novel}

The author of Virāgaya makes a conscious attempt at understanding the postcolonial Sinhala person, and in the process, the novelist criticizes some aspects of this person and admires some other aspects, and even warns us against some other characteristics. The novelist's alter-ego Sammy coming to Ginpataliya, which is Aravinda's native village, to find out Aravinda's whereabouts indicates the extent to which the novelist investigates this postcolonial Sinhala person. Sammy, the narrator of the framing narrative, is like an investigator looking into Aravinda's personhood. Like the framing narrative of The Heart of Darkness, the outer frame of Virāgaya too immediately prepares for a journey into one man's soul. ${ }^{14}$ With this character, we the readers are also invited to participate in the investigation. This is how Sammy describes Aravinda:

I have known scholars, pundits, writers, intellectuals, metaphysicians, astrologers, exorcists, holy men. I never really could place Aravinda Jayasena, however. I had spent many hours talking to him, arguing with him. Despite all this I found myself quite incapable of fathoming his personality. Sometimes he would argue like an intellectual; at other times he would cling to quite irrational

election victory in 1956. By extension then, president Mahinda Rajapaksha's ascent to power in 2005 may be seen as a turning point in postcolonial Sri Lanka. One could even argue that a certain ideological trend that originated in 1956 (Bandaranaike) reached a logical end in 2005 (Rajapaksha).

${ }^{14}$ In the way the narratives are framed, The Heart of Darkness and Virāgaya are remarkably similar. Looking for Kurtz, Marlow goes into African wilderness, and looking for Aravinda, Samy goes into rural Sri Lanka. In the first novel, Kurtz is a creation of colonial imperialism, and in the second novel, Aravinda is very much a product of the socio-economic structures created by colonialism. 
ideas; and yet again he would seem to be a slave to the most immature and sentimental impulses. $(3)^{15}$

Sammy, a character that Wickramasinghe has often used as his alter-ego, who is a disinterested observer or an examiner of other characters, seems to be a representative of the modern scientific man. What Sammy does at the opening of the novel is to get the reader into a kind of objectivist investigative mode in order to understand Aravinda. Then, we are given a chance to read Aravinda's autobiography. An autobiography is a confession, a dream or a fantasy, and therefore, Aravinda's autobiography is an invitation to psycho-analyze Aravinda. Psychoanalytic objectivity with which the author approaches the main character, i.e. the subject, who is a man trapped in two traditions, reminds one of the way the colonizers 'scientifically analyzed' the natives in numerous colonies. After all, the psychoanalytic approach is a legacy of colonial modernity. ${ }^{16}$

When Sammy comes to Aravinda's village to 'look for' him Aravinda is already dead, and since the novel was published in 1956, one could argue that Aravinda died around that time. What we find is Aravinda's autobiography, and with that we get an opportunity to 'look into' him. This was exactly what happens in The Heart of Darkness as well-a well-known text often read as a postcolonial one. Though may be accidental, the narrative structures of the two novels are quite similar to each other. Both novels have formal tools that are fitting and necessary for the kind of investigations that the books have chosen to engage in.

In historicizing Virāgaya, we must ask ourselves why the author wants to 'psycho-analyze' a character like Aravinda in the middle of the Twentieth Century. My contention is that Wickramasinghe wanted to closely look into the inner make-up of the Sinhala Buddhist modern

\footnotetext{
${ }^{15}$ While I use both the original Sinhala text and its translation in this paper, I will quote primarily from the English translation admirably rendered to English by Professor Ashley Halpe.

${ }^{16}$ Loomba includes a brief summary of some studies that look into the psychology of the colonizers and colonized. Nandy is perhaps the best of such studies by a South Asian scholar after the famous studies by Fanon. Nandy explains how colonialism creates a split-subjectivity within the colonized once the colonizer portrays himself as superior to the colonized.
} 
citizen who is inevitably a product of many influences. If we date Aravinda's death to 1956 (or around that year) it may appear that his death signifies the death of certain colonial unrest. Or it is even possible that the novel indicates possible postcolonial unrest in consciousness. Let us focus on this issue of consciousness.

The author is meticulous about showing that Aravinda is a product of two traditions: Eastern and Western. This is how Sammy the narrator of the framing narrative describes the belongings of Aravinda, which are now stored in a room after their owner's death:

English, Sanskrit and Pali books, some bound in leather, some in cloth, languished in the cupboard, deprived of the care of the enigmatic scholar who had handled them so often. As I read the titles of the books on chemistry, Buddhist metaphysics, occultism, magic, and psychic research, it occurred to me that I had not been far wrong in my original evaluation of Aravinda's mind. A bronze statue of the Buddha stood on a little table. Near it was a pile of olaleaf manuscripts. I turned up one of them and tried to read a leaf. Apparently it was about the kind of magic and the occult practices that the Buddha called the absurd science. The statue seemed to preside over the ola-leaf manuscripts and books. (07)

The objects described in this paragraph indicate the nature of the owner of them. In the next paragraph, the author says, "The room was a veritable museum, and looked like a memorial to the inner life of the dead Aravinda (7)."17

From his boyhood Aravinda was exposed to two traditions: the native and the Western. The native influence, i.e. the Sinhala Buddhist influence on him, however, appears to be much more pronounced. The novel must be put into a historical context to understand Aravinda's sources of influence. Unlike in Wickramasinghe's other novels, such as Gamperaliya, the time period of Virāgaya is not indicated directly or

\footnotetext{
${ }^{17}$ The expression 'the inner life' is not found in the original text. Translated literally, the relevant sentence should read as follows: "Siridasa took out a certain pouch from this museum which is like a grave house in which Aravinda's souls resides." When Halpe renders atmaya as 'the inner life' he is indicating the fact that Virägaya is a modernist novel that concerns itself with the interior landscape of individuals.
} 
indirectly. The major political or other social events that occurred during the time in which the novel is set are not mentioned either. Wicrkamasinge may have wanted this book to be an abstract metaphor for the modern 'Sinhala person' that is not bound to any specific time period. That is how at least the book has been read. In this paper, I want to situate the book in a specific time period and show that such contextualization helps us read the book as a postcolonial text. ${ }^{18}$

In the first paragraph of the first chapter of his autobiography, Aravinda says:

Father had a great reputation as a physician in our part of the country. The villagers were full of praise for him, and they often brought him gifts when they came to see him. But father was usually very taciturn in company. When I recall him as he was in those days-he died soon after I passed the English Senior ExaminationI realize that I hardly ever saw him smile. (10)

One crucial piece of information in this paragraph is the 'English senior examination,' which is part of colonial education. This is not the only 'sign of historicity' in the first chapter; there are other such signs: Aravinda's father knew Pali, Sanskrit and English. He sends Aravinda to an English school and wants to make him a doctor because he thinks that Western medicine is 'superior' to Eastern medicine.

Aravinda's coming of age (or failing to come of age) takes place at a time when two different traditions intersect making him attracted to both. Here is Aravinda's description of his education in the English medium school and his own curiosities generated by that education.

Chemistry was as much an occult science to me then as magic and alchemy-I saw little difference between them. I have a dim notion that by the exploration of one or the other of these arts I could acquire the power of performing prodigies, and discover the key to all the secrets of the universe. Explosives and fireworks were marvelous inventions. Chemistry, alchemy, magic - to my mind the words were

\footnotetext{
${ }^{18}$ When the veteran filmmaker Tissa Abeysekara wrote his script for Virāgaya, he situated the earliest point of the story, when Aravinda was a teenager, in 1930, and I generally agree with this dating.
} 
lumps of salt out of the same sack. I has heard well-read people, and sometimes even my father, say that modern science was as worthy of study as the Abhidharma. Of course, my father wanted me to study chemistry only because he thought it a certain path to a high government job. I was attracted to it for a very different reason. I thought that it would unravel for me the mysteries of the universe. (26)

In the same description, Aravinda reveals that though he read science fiction and he was 'second in the class in science,' he avoided studying science textbooks and he conducted his own experiments on chemical reactions learning formulas from books such as 'The Marvels of Chemistry' (26). Aravinda continues these experiments even as an adult, and once a huge explosion occurs injuring him, an incident that was crucial for Aravinda's leaving his ancestral home as his sister prohibits him conducting such experiments fearing that they would harm her young son. Western science, introduced to Sri Lanka through the colonial contact, effectively drives Aravinda into a life of his own, and a job as a clerk, a position that came into being with the colonial administrative structure, helps him support himself to live an independent life. Thus, it is clear that Aravinda's internal dualities have their origin in the colonial/postcolonial society in which he was born and raised.

Another sign of history that appears in the first chapter is the father's wedding photo in which the father is dressed in "some kind of a fancy-dress" - as Aravinda sees it: "He wore trousers, but with a cloth draped over them. He had a frock-coat reaching to his knees, he had a tie, socks, and shoes" (15). This dress was common among upper middle class people during the colonial times. It is important to note here that to Aravinda this dress of his father "[looks] very odd" (15). The fact that Aravinda finds his father's wedding dress to be odd is significant when we view this text as a postcolonial one. Describing the photo, Arvavinda further says, "Mother stood behind him. She wore a long gown and gloves, and carried a fan. Even village people who saw this photograph today would imagine that she was dressed up to act in a play or something like that" (15, emphasis mine). 
In this description, the word "today" establishes the postcolonial moment in the text. It is further strengthened by the expression, "to act in a play." To Aravinda, that attire is not real; it is fake and it looks like something worn by a character in a play. These expressions make it clear that the time of direct colonial influence on peoples' life has already passed. 'Today' or the 'present' here indicates a point in time immediately prior to or immediately after the independence. Aravinda's gaze at the photograph is postcolonial, and the moment such dress codes were in vogue has now passed. In the early period of colonial contact, rural middle classes were a bit hesitant to accept the Western attire. The cloth draped over the trousers, like a sarong over pants, signifies that hesitance. By the time of Aravinda, the fusion or confusion of the two cultures seems to have been over.

Wickramasinghe is great in the way he registers the historicity of the novel by describing two wedding photographs. Here is the other photo:

On the opposite wall was my sister's wedding photograph. This was very different. My sister was wearing a saree and a blouse, ad she carried a bouquet of flowers, her husband was simply dressed in coat and trousers. In fact my sister would look like any bride of today if it were not for her chalky face and affected droop of the head. (15)

The rest of the chapter makes it clear that Aravinda as a schoolboy is struggling to resolve a conflict in him.

\section{'Detached Desire' - A Central Theme}

Aravinda's virāgaya ('detached desire' or 'desireless desire') is the main characteristic that distinguishes him from the other characters in the novel. ${ }^{19}$ The central event that dramatizes this 'virāgaya mentality'

\footnotetext{
${ }^{19}$ The term 'virāgaya' is extremely difficult to translate. Halpe who subsequently translated the novel into English draws attention to this difficulty: "Viragaya includes such a range of significance as to be virtually untranslatable. Perhaps its most inclusive meaning is that it signifies a state in which "all desires, passions, feelings, beliefs and thoughts are purged from the mind of the contemplator. (Mr. Wickramasinghe, in a letter to the present writer). The words detachment, nonattachment, passionlessness all partial and inadequate equivalents." (228)
} 
is the fact that Aravinda loves Sarojini without making an effort to 'own' her by marrying her. Other than that event, in this novel of minimal drama, there is no other real event to represent Aravinda's detachment (virāgaya). His attitude towards education and its use for social mobility too could be read as another expression of virāgaya or detachedness. Even though Aravinda is good in his studies, he has no ambition to rise up in the society. In that sense, the term virāgaya means the lack of ambitiousness.' He is curious about everything in the world, but for him education is not a tool to be used to become rich, powerful and so on. This mental disposition is a complex one compared to the nature of many others in the novel. His curiosity of science is mediated by a detachedness he has inherited from the Buddhism.

Another characteristic that signifies his virāgaya is his generosity towards people around him. When his sister practically steals the house that he should have inherited, he gives it away with Bodhisattva-like indifference and grace. ${ }^{20} \mathrm{He}$ helps out his household servant and her daughter Bathee, as if they were his own family. As a clerk in the government clerical service, Aravinda's income is more than enough for his expenses ${ }^{21}$ and he spends that money first to educate Bathee and then to marry her off. He buys her a car (a used Ford car) and gives the bridegroom a cash-dowry - an act that angers Aravinda's miserly sister who accuses him of spending money on people who are not related to him. Aravinda argues that it was his responsibility to help Bathee and her mother who have been taking care of him.

By specially focusing on this unique character Aravinda, Martin Wickramasinghe seems to be meditating on one of the key possible characteristics of the postcolonial Sinhala person. A statement Wickramasinge made nine years after the publication of Virägaya, which

\footnotetext{
${ }^{20}$ In his book-length exposition of his own novel Virāgaya, Wickramasinghe explains that Aravinda was a genuine lay Buddhist who consciously or unconsciously attempted to enter the 'path' the Buddha taught (Navakathāmga hā Virāgaya 467). In fact, Wickramasinghe claims that Aravinda could be considered a sakrdāgāmi, one who has attained the second stage of the path towards Buddhist Enlightenment (469).
}

${ }^{21}$ Aravinda himself says, "As a clerk, my salary is more than enough for me" (129). 
had then become the most talked about Sinhala novel ever, highlights the postcolonial significance of the novel:

Buddhist environment and village culture, which was changed by some moral codes of Western culture, shaped Aravinda's mind, and his mind was like a container that accepts any wrong belief (avichara matayak). His soul is close to the soul of someone who thinned out 'I-ness.' The codes of moral conduct related to monastic life and some moral codes or 'good customs' of the West were hypocrisies that destroy the household life and its comfort of the villagers. Those hypocrisies were confusing (sankara) model codes that discipline Buddhists according the moral conducts of monks. That was not a Buddhist moral code. The Buddha did not teach a lay moral code that never changes...The majority of those lay people, who live paying lip service to monastic moral codes which do not belong in the Buddhist lay culture, are hypocrites. Those who try to live without being hypocrites live like ones who have been exiled from the Buddhist society. The society shaped by a mixed culture is the one that treats people like Aravinda as fools, hypocrites, weaklings and losers. That culture is devoid of the core meanings of both Western and Buddhist cultures (Wickramasinghe, Navakathāmga hā Virāgaya 99).

This paragraph shows that more than any other critic Wickramasinghe himself knew the postcolonial potentials of his novel. When no other could see the postcolonial meanings of the novel, Wickramasinghe himself had to step in to remind us that Aravinda was a historical creation rather than a universal and trans-historical representative of the ideal person. In other words, the author himself has known, more than anyone else, that colonialism could create split consciousnesses in subjects and that such split consciousnesses could continue well into postcolonial contexts long after the end of direct colonialism.

\section{To Marry or Not to Marry}

As the above quote suggests, Wickramasinghe does not uncritically endorse Aravinda. While respecting Aravinda's Bodhisattvalike qualities, he criticizes Aravinda's uncritical acceptance of the codes 
of ethic that were meant for monks rather than for lay people. The invasion of monastic ethics into the domain of secular lay life is subjected to the author's critical scrutiny. In many other essays, Wickramasinghe reminds the Sinhala people of the need to keep the monastic ethics at bay, implying that unchecked acceptance of those moral codes would lead to hypocrisy than to ideal personhood. At the same time, Western morality is not devoid of hypocrisy, argues Wickramasinghe.

It is not clear in Virāgaya, how Western morality, Victorian ethics for example, intervenes in the life of Aravinda and others. One may argue, however, that the idea of monogamous marriage, which is a recurring trope in the novel, signifies the Western moral codes of sexuality. At the beginning of the novel, for example, we see Aravinda reflecting on his parents' wedding photo. Then, his gaze moves onto the wedding photo of his sister. The key drama of the novel also revolves around marriage. That is the 'marriage' of Sarojini and Aravinda. That conflict is resolved with Siridasa and Sarojini's marriage. Aravinda is rejected by society, and he is gossiped about because he is not married and he lives with women who are not married to him. In a way, Aravinda's isolation results from his rejection of marriage. The codes of ethic around rural marriage and sexuality are shaped not only by monastic morality but also by Western morality. The fact that Aravinda lives with two women generates suspicion about his sexuality. That is why Bathee who is almost his adopted daughter and much younger than him is a cause for gossip. Many villagers do not understand any other heterosexual relationship beyond marriage. ${ }^{22}$ Aravinda himself seems to accept these norms and monastic sexual codes without much resistance. His confessions invite us to closely engage with the effects of this morality on him.

Moreover, the next big dramatic event in the novel is also centered around a marriage. Aravinda's inaction and indecision return when Bathee falls in love with a man:

\footnotetext{
${ }^{22}$ Interestingly, no one in the village interprets Aravinda as having gone two steps towards the Buddhist enlightenment, as Wickramasinghe himself claims.
} 
What was I to do? I ought to throw both Bathee and her mother out of the house. Or I should at least get rid of Bathee or if that too wouldn't do I ought to get her married off to this young man with whom she was in love. But I did not have courage to do any of these things. To send her away after bringing her up for eight years, would be a vile thing to do. And her mother, who has seen everything about the house for so long now-how could I throw her out either? And how could I give Bathee to some ruffian of a driver. (119)

Even though his own loneliness or single life results from the fact that he did not marry the girl he loved, Aravinda fails to understand that Bathee's happiness might depend on marrying her boyfriend. Aravinda's initial reaction to this relationship is quite conventional. $\mathrm{He}$ accuses both Bathee and her lover for falling in love without proper plans for getting married.

By the time of Aravinda's generation, however, the 'purely indigenous' married life had disappeared due to the country's contact with the West. Married life (or the lack of it), the central narrative locus in which Virāgaya's thematic drama takes place, is a postcolonial one. In other words, the idea of being married, which animates the novel's central plot, is 'postcolonial.' This is seen in the way Aravinda comments on family life:

In our country husbands and wives regard the use of words like "darling," "my treasure," "my life," "beloved," to be as bad as kissing or embracing in public. They do not believe in making a parade of intimacy, and their relationships are inward and inarticulate. This was how father and mother, too, lived" (52).

Not only are the 'marriage scenes' in Virägaya central to the novel's theme, they also mark the postcoloniality of the text. The customs, ethics and laws about marriage in the novel are very much a product of two traditions. Compared to the relatively loose pre-colonial marriage customs and laws described by European visitors and colonial administrators, ${ }^{23}$ 'love' and 'marriage' in Virāgaya have been clearly

\footnotetext{
${ }^{23}$ Based on the colonial accounts of marriage in Ceylon, Pieris has shown that people in the Kandyan kingdom, i.e. the central Sri Lanka, were very relaxed about their marriage customs and sexuality. People easily moved in and out of marriage,
} 
shaped by the colonial contact. If one were to accept at least some of the accounts produced by Johann Wolgang Heydt, a German who worked for the Dutch East India Company in 1771, he or she could see that marriage had not been a 'big deal,' big enough to animate the thematics of a novel: "When (the people of Ceylon) marry they make little ado about it... As soon as the parents have arranged it, the bridegroom must send a petticoat of quite low value to the bride or himself take it..." (qtd in Peiris 7). Many accounts of pre-colonial marriage customs in Sri Lanka suggest that at least in rural areas and lower social strata, marriage and the handling of sexuality were indeed done without much ado. By the time of Aravinda, the early Twentieth Century, marriage had turned into a big deal with several new norms, laws, and rituals associated with it.

Apart from the sexual morality associated with marriage, the economics of 'marriage' influenced by the West is key to an understanding of the central drama of Virägaya. Aravinda loses the ancestral house, which he should have inherited according to the tradition, to his brother-in-law because of the kind of wedding Aravinda's father wanted for his daughter: "He had spent lavishly on Menaka's wedding" (70). The marriage costs the family their house. This wedding is very different from the kind of wedding where the bridegroom sends a "petticoat of quite low value to the bride":

The local personages who came to the wedding were feasted sumptuously - this was just the sort of thing he took delight in doing. Later, he would preen himself proudly when he told some friend or relation, "Ratnajeeva Vasala Mudali and District Judge Yatisena did me the honour of coming to the wedding." We regarded

and the husbands were not jealous that their wives had other sexual partners. Marriage had been considered a simple and inevitable event in one's personal life, and people have made very little fuss about it. The divorce had been quite common and so had been remarrying. According to a colonial account a marriage could be "established with a wink and cancelled with a kick"(p. 1995). Based on his field research in the 1960s, Yalman shows that in the Kandyan regions, at least among the peasantry, marriage had been a simple affair, and a marriage is formed when a man and a woman began to cook their food together (102-106). 
Ratnajeeva Mudali and the District judge with almost as much respect as if they were royal visitors. (71)

As Aravinda explains it, "for five days before the wedding father threw himself into an orgy of spending" and "at least twenty people had to be fed at every meal during those hectic days." The bride's dress, a "quite new style," was done by Ilangaranga Vasala Mudali's daughters who had ruined themselves economically by 'wastefully' imitating lavish Western ways" (71).

The 'bankruptcy' that the Ilangaranga family ends up with as a result of imitating Western ways in fact foreshadows what is to happen to Aravinda's family, for the wedding puts Aravinda's father also in debt. He borrows money from his son-in-law, writing the house off to him by a deed since he could not ever repay the debt. The list of invitees for the wedding also signifies the social status and hierarchy of the colonial times: "We regarded Ratnajeewa Mudali and the District judge with almost as much respect as if they were royal visitors" (71). The family has spent lavishly to have a wedding reception in a manner that is fitting to welcome colonial officers such as 'Mudalis' and 'judges.' By attempting to acquire this kind of symbolic capital in order to be able to say "such and such dignitaries came to our wedding," without having real capital to afford it, the family loses its house.

Thus, Menaka and Dharmadasa gain the ownership of the ancestral house, which should traditionally be inherited by the younger son Aravinda. This is the main reason why he becomes an aloof character. With this unexpected turn of events, Aravinda's mother who does not like living in 'somebody else's house' is disappointed that her husband did not make any plans for her future, and she returns to her own ancestral village. This is another factor that makes Aravinda's solitary life possible, and, in terms of realism, believable. The economy of the modern wedding, with several colonial elements to it, is quite important in creating the causality of the novel and portraying Aravinda's character. Right after losing his house, Aravinda gives up further studies and takes the clerical exam. 


\section{The Importance of Being a Clerk}

The adult Aravinda's independence and detachment from the rest of the village are made possible by his employment. The position of the clerk is very much part of the colonial administrative structure. Aravinda's 'detachment' as a cultural attribute looks essentially Buddhist. But when one lives as a lay person in modern world, enmeshed in a network of social relationships, a mere religio-cultural concept such as detachment alone cannot sustain such a life. One has to pay his bills. A dependable source of income or financial support is the necessary foundation on which one's preferred way of life rests. Even a person with a detached life has some bills to pay. For Aravinda, the only source of income is his job as a clerk in the colonial government. Being a clerk in the Ceylon Clerical Service in the early part of the Twentieth Century in which the novel is set was a prestigious occupation. Aravinda is a man of few needs. His lifestyle is rather simple, and his detachment from the pleasures of lay life makes it possible for him to live a frugal life. But it is his salary that gives him a great deal of freedom to live the life he wants.

It is clear in the novel that Aravinda does not receive any income from his ancestral land, which is not profitable anyway. The ancestral house which is normally inherited by the younger male child of a family does not belong to Aravinda even though he has all the qualifications to inherit it. Usually, middle class Sinhala villagers have at least some land and paddy to live on. It is significant that Wickramasinghe does not mention any such land or sources of income. Aravinda's economic independence is made possible by his position in the structure of colonial political economy, which is outside of the village. The novel does not give us any information as to how Aravinda worked as a clerk, and no scene at his office is described. His 'office' figures in the novel only in the form of his salary, which is mentioned several times. Even though he does not like to be a Western physician, he spends his adult life as a government clerk. One can argue that colonial education, in its original plan at least, aimed at producing second level administrators such as clerks. For Aravinda, however, his position as a clerk gives him more than what the colonial government intended. His 'detached life' is made possible mainly by his job as a clerk, not just by his Buddhist upbringing. Thus, the 
'Aravinda consciousness' for which the novel is largely known in the Sinhala literary history has an economic foundation as well as a cultural one. The economic foundation (the clerical service) is laid by colonialism and the cultural one (the idea of detachment) is given by Buddhist culture.

When his sister and her husbands end up owning the ancestral house, Aravinda does not hesitate to leave it and live in a house of his own. That is one of the few places where he breaks free of his characteristic 'inaction.' This 'action' was made possible by his stable income as a clerk: he was making Rs. 80 a month. His economic independence was enabled not just by his 'Bodhisattva way of life' but also by his job in the Ceylon Clerical Service.

To historicize Aravinda's independent thinking and aloofness he keeps from his rural community, I wanted to look into the history of the Clerical Service in Ceylon/Sri Lanka and the ways it changed the lives of young men in the country at the beginning of colonial modernity. While there is hardly any research on this subject, what I have found so far is fascinating. A report by a committee appointed to improve the clerical service in 1899 states that the system of admission to the service was the "fairest." It was an exam for which "specimen papers come from England. Arithmetic and English were among the subjects required." Once one is admitted to the service, "merit and seniority" were the only criteria for promotions. Let me quote a paragraph from the report which throws some light on how people like Aravinda was historically created in rural Sri Lanka:

It will be observed that we have fixed the initial salary of a passed candidate as RS.500 we consider this sufficient for a lad commencing life, who should have no embarrassing ties, and will the proposed incremental system have assured prospect of rising to a moderate competence within a definite period. ("The Ceylon Clerical Service" 39)

According to the new proposals, a "diligent clerk will rise to a salary of Rs. 1100 in nine years" (40). Aravinda is such 'a lad commencing life;' he too did not have 'embarrassing ties' in his life. According to the Report, the Ceylon Clerical Service has had an 
elaborate system of grades. Aravinda was arguably at one of the lower grades. However, his salary as a clerk would have given him a formidable income.

When the colonial government improved the Clerical Service in Ceylon in 1898 by appointing a three-member Committee comprised of L.F. Lee, H.L. Crawford and R.A. Brohier it intended to create clerks like Aravinda who do not have major financial worries. The Clerical Service, among other colonial Services of the colonial government, created opportunities for young men of relatively high education to enter a life of financial security. The Clerical Service had an elaborate promotion system that rewarded ambitious men. In his preamble to the committee report on the improvement of the Clerical Service, Governor J. West Ridgeway says:

It is proposed by the Committee that in future the Clerical Service will be divided into four classes: first, a special class including appointments of RS. 3000 and upwards, to which promotion will be merit alone. Secondly, what will be known in future as the first, with salaries rising from RS. 1800 by annual increment of RS. 100 to RS. 2400. A suggestion has been made that clerks of thirty years standing should be allowed to earn an additional increment of RS. 100 to bring up their salaries to RS. 2500 , and I am prepared to accept this proposal. It will not make any practical addition to the cost of the scheme. The next class from RS. 1200 to 1600 and the third and or lowest will begin on RS. 500 and rise by increments to RS. 1000. Promotion from lower to higher class will be by merit and seniority combined. $(37)^{24}$

It is obvious that Governor Ridgway in his letter to the British Parliament is very much in support of the proposed changes to the Clerical Service. Aravinda of Virāgaya is largely a product of these new changes in the Service. ${ }^{25}$ The Clerical Service may have had a far

\footnotetext{
${ }^{24}$ Wilson includes a detailed description of the origin and development of the Colonial Clerical Service in Ceylon and points out that the colonial administration paid special attention to the Clerical Service since that was essential to govern the colonized (207).

${ }^{25}$ It is difficult to discern the exact time period in which the story of the novel is set. There are some indirect signs that indicate that the story could have taken place
} 
reaching impact in rural Sri Lanka offering a desirable profession to educated young men. ${ }^{26}$ Aravinda symbolizes a certain subjectivity that the colonial condition could have created. ${ }^{27}$

Another interesting character who lives significantly separated from his community is coupled with Aravinda, and he sheds important light on the nature of Aravinda. He is Kulasuriya, a postmaster. Aravinda chooses the postmaster as his mentor and discussion partner

sometime closer to the second quarter of the Twentieth Century. Aravinda's annual salary as a clerk is little over one thousand rupees. It is possible that he is a clerk in the lowest class.

${ }^{26}$ During the present research, I found out that the fathers of many well-known academics were clerks in the early decades of the Twentieth Century.

${ }^{27}$ When the veteran filmmaker Tissa Abeysekara turned Virāgaya into a cinematic masterpiece, he seems to have been much more alert to the significance of Aravinda's being a clerk in the colonial clerical service. Though the novel does not contain any scene depicting Aravinda's office or the nature of his work, Abeysekara who also wrote the script creates several carefully crafted scenes of Aravinda's office. One of them shows Aravinda assuming duties as a clerk, and this is how the script writer describes Aravinda's office and its surrounding:

\section{A Government Office; Inside; Day}

The Galle Fort and the ocean beyond are seen from an open window. On this side of the window is a small room of a government office. A photograph of King George the Fifth is hung on the wall. Below the photograph, a government official is seated at a table. He carefully examines some documents. He is a Sinhala person. But his attire and demeanor shows that he is heavily imitating his English masters. His hat and coat are hung on a hanger nearby. Close to them, beneath the king's photo, there is a photo of a white government agent. A peon meekly enters the room.

Peon: Sir. The new clerk has come.

Then the way the official theatrically accepts Aravinda's appointment letter is described in detail.

Officer: Aravinda Jayasena! The most important thing that is expected from a government servant is loyalty to the state. Complete loyalty. Jayasena needs to remember that neither I nor Mr. Agent (Government Agent) is your boss.

He points to the Agent's photo. Then he points at the British Emperor's photo, and certain sense grandeur and awe come on to his face.

Officer: King George the Fifth of England!

(Abeysekara. Virāgaya: Tira Racanaya 74-5). 
on stuff 'beyond-everyday,' topics such as the meaning of life. This is how Aravinda reflects on Kulasuriya: "Kulasuriya lived the life of an outcast. Menaka (sister) was afraid that I would crawl away from society too. That's why she had said, 'I can see you've caught Kulasuriya's disease" (123, emphasis mine).

Kulasuriya ignored society. He knew just a few people, and he always regarded us as individuals - not as mere units of society (104, emphasis mine). Kulasuriya's life as an individual not just as a member of society is also made possible by his being a postmaster-an important position in the colonial administrative structure-and a very influential rural job in the early decades of the Twentieth Century. Similarly, Aravinda's relative independence from the rest of his society is made possible by his occupation. In addition, Kulasuriya is a comparable conversation partner for Aravinda. It is particularly significant since Aravinda has no association with typical learned people in villages, such as Buddhist monks. In his famous treatise on his own novel, Wickramasinghe (Navakathanga ha Virāgaya 465) clearly states that he did not portray Aravinda as someone influenced by "Buddhist monks, Buddhist temples...." At the same time, there is no place in the novel where Aravinda is seen visiting a temple or in conversation with a Buddhist monk. Nearly all his intellectual conversations are with Kulasuriya, a secular and independent thinker, which shows that Aravinda's consciousness is shaped by secular ideas of colonial modernity.

\section{Thematic Summary}

Virāgaya is a novel that does not include any major political event or political ideas in the background or in the narrative. No one in the novel talks politics. This 'political silence' is quite interesting and peculiar considering the time in which the novel was written and the times in which the novel is set. However, when the novel is historicized as a postcolonial text, it begins to speak to the 'political' in a very different sense of the term, and that 'political' is perhaps much more important since it intervenes in the discourse on the postcolonial Sinhala person and his or her possible forms of subjectivity. Dissanayake is right in claiming that Amarasekara as a novelist and a critic "stressed the 
importance of history in a social analysis" (183). In the analysis of Virāgaya Amarasekara and other critics failed to take into consideration the postcoloniality of the text, which is an important part of 'history. ${ }^{28}$ The novel provides a paradigm to reflect on possible dilemmas, failures and virtues of the ideal person in postcolonial Sri Lanka. The main goal of this paper was to argue that Virägaya, which has been criticized for being isolated from the 'socio-political dialogue,' is in fact a significantly social text and, therefore, a political text. In his examination of the inner make-up of the postcolonial Sinhala (Buddhist) person, Wickramasinghe remains ambivalent without being conclusive. That sense of indeterminacy results from his fiction writing influenced by modernism. Regarding Aravinda, the central character of the novel, one could only say that his subjectivity is created both by the native culture and the colonial structure. The known concepts in postcolonial discourse, such as Bhabha's 'mimicry,' 'hybridity,' and 'ambivalence,' or Chatterjee's 'inner and outer domains' and the like do not fully help us understand Aravinda, the person. And the traditional theories of economic determinism in classical Marxism help us even less in this task. Any nativist explanations, such as the Buddhist culture created Aravinda, also do not provide us with a convincing explanation. Therefore, I agree with the following statement by Bhabha:

Postcolonial perspective - as it is being developed by cultural historians and literary theorists - departs from the traditions of the sociology of underdevelopment or 'dependency' theory. As a mode of analysis, it attempts to revise those nationalist or 'nativist' pedagogies that set up the relation of Third World and First World in a binary structure of opposition. The postcolonial perspective resists the attempt at holistic forms of social explanation. It forces a recognition of the more complex cultural and political boundaries that exist on the cusp of these often opposed political spheres. It is from this hybrid location of cultural value-the transnational as the translational-that the postcolonial intellectual attempts to elaborate a historical and literary project. (173)

\footnotetext{
${ }^{28}$ Wimal Dissanayake whose book has the potential of contributing to the current debates in postcoloniality only discusses Wickramasinghe's famous trilogy and its socio-political thematic. Virāgaya does not even receive a passing remark there.
} 
When I claim that Aravinda's detachment or virāgaya is made possible by both the native culture and the colonial structure (i.e. postcolonial condition), I locate that consciousness in the 'hybrid location of cultural value' - the phrases I emphasized in above quote from Bhabha.

\section{Works Cited}

Abeysekara, Tissa. Virāgaya: Tira Racanaya. Battaramulla: Mudra Prakashana, 1992.

---. Roots, Reflections and Reminiscences. 2007. Nugegoda: Sarasavi, 2009.

Amarasekara, Gunadasa. Abuddassa Yugayak. 1976. Boralesgamuwa: Visidunu, 1996.

---. Nosevnā Kædapata. Boralesgamuwa: Visidunu, 2008.

Bhabha, Homi. K. The Location of Culture. London: Routledge, 1994.

Chatterjee, Partha. The Nation and its Fragments. Princeton: Princeton University Press, 1993.

Dharmadasa, K.N.O. Preface ["Hevanella (the Shadow) in the Historical Context of Modern Sinhala Literature"] The Shadow by Siri

Gunasinghe. Trans. Hemamali Gunasinghe. Colombo: Vijitha Yapa, 2010.

Dissanayake, Wimal. Sinhala Novel and the Public Sphere. Boralesgamuwa: Visidunu, 2009.

Halpe, Ashley. "Beyond Passion: Some Comments on the Theme and Structure of Virāgaya." Martin Wickramasinghe: The Sage of Koggala, edited by Rupa Saparamadu, Dehiwala: Thisara Publishers, 1975. pp. 228-35.

Hapuaracchi, V. Mārțin Wikramasiṃhagē Navakathā saha Kețikathā. Maharagama: Saman, 1961.

Loomba, Ania. Colonialism / Postcolonialism. London: Routledge, 2000. Nandy, Ashis. The Intimate Enemy: Loss and Recovery of Self under Colonialism. 1983. Delhi: Oxford University Press, 1999.

Peiris, Edmund. "Marriage Customs and Ceremonies in Ceylon." The Journal of the Ceylon Branch of the Royal Asiatic Society (New Series), vol. 8, part 1,1962, pp. 1-28. 
Rambukwella, Harshana. The Politics and Poetics of Authenticity: A Cultural Genealogy of Sinhala Nationalism. London: University College London, 2018.

Sarathchandra, E. R. The Sinhalese Novel. Colombo: Gunasena, 1950.

---. Siṃhala Navakatā Itihāsaya hā Vicāraya. 1951. Nugegoda: Sarasavi, 2011.

Suravira, A.V. Sāhitya Vicāra Saṃhitā. Colombo: Godage Publishers, 1996.

Watt, Ian. The Rise of the Novel. 1957. Berkeley: University of California Press, 1984.

---. "The Ceylon Clerical Service" in Papers Laid before The Legislative Council of Ceylon during the Session of 1898. Colombo: Government Printer, 1899.

Wickramasinghe, Martin. Virāgaya: The Way of the Lotus. Translated by Ashley Halpe, Dehiwala: Tisara Prakasakayo, 1985.

---. Virāgaya. Nawala: Sarasa Prakashakayo, 2008.

---. Navakathāṃga hā Virāgaya. Dehiwala: Thisara Prakashakayo, 1992.

---. Samāja Dēśapālana Cintana, edited by W.A. Abeysinhe, Nawala: Sarasa Publishers, 2016.

Wijegunasinghe, Piyasili. Nūtana Siṃhala Sāhitya Vicāraya: Makswaadi Adyanayak. Angoda: Sanivedana Prakashakayo, 1987.

Williams, Raymond. Politics of Modernism: Against the New Conformists. London: Verso, 1989.

Wilson, A. Jeyarathnam. "Public Administration in Ceylon" Public Administration in South and Southeast Asia, edited by S.S. Hsueh, Brussels: International Institute of Administrative Sciences, 1962. Yalman, Nur. Under the Bo Tree. Berkley: University of California Press. 1967. 